\title{
KEPRIBADIAN DALAM TEORI SIGMOUND FREUD DAN NAFSIOLOGI DALAM ISLAM
}

\author{
Syaiful Hamali \\ UIN Raden Intan Lampung \\ syaifulbamali@radenintan.ac.id
}

\begin{abstract}
Personality possessed by someone shows the totality of individual buman nature, both in physical and psychological form as a distinction between one buman and another buman, personality is formed from the results of the interaction of individuals with individual living environments. Whereas in personality psychology describe the overall character possessed by Muslim individuals, both displayed in the form of visible and invisible behavior. The personality displayed by a Muslim as a result of the influence of his religion. In other words, personality is a mechanism that works within the individual because the way of thinking, behaving, reacting and behaving cannot be separated from the beliefs or beliefs they hold, because the beliefs they hold are included in the personality structure.
\end{abstract}

\begin{abstract}
Abstrak
Kepribadian yang dimiliki oleh seseorang menunjukkan totalitas sifat kemanusiaan individu, baik dalam bentuk fisik maupun psikis sebagai pembedakan antara manusia satu dengan manusia lainnya, kepribadian terbentuk dari hasil interaksi individu dengan lingkungan tempat tinggal induvidu. Sedangkan dalam nafsiologi kepribadian menggambarkan keseluruban karakter yang dimiliki oleh individu yang muslim, baik yang ditampilkan dalam bentuk tingkah laku yang kelihatan maupun yang tidak kelihatan. Kepribadian yang ditampilkan oleb seoran muslim sebagai akibat dari pengaruh agama yang dianutnya. Dengan kata lain
\end{abstract}


bahwa keppribadian adalah mekanism yang, berkerja dalam diri individu karena cara berfikir, bersikap, bereaksi dan bertingkah laku tidak dapat dipisabkan dari kepercayaan atau keyakinannya yang dianutnya, disebabkan kenyakinan yang dianutnya itu termasuk dalam struktur kepribadian

Keywords: Personality Theory, Freud Sigmound, Islamic Nafsiology

\section{A. Pendahuluan}

Dalam psikologi dikatakan bahwa kepribadian adalah organisasi yang selalu bergerak dalam diri individu yang terdiri atas berbagai sistem jasmaniah dan rohaniah, dan bekerja sebagai penentu dalam menyesuaikn diri pada lingkungannya. Malik B. Badri, psikolog muslim, menyatakan Sigmund Freud adalah salah seorang tokoh psikologi Barat yang sering dikritik oleh psikolog Muslim, karena psikoanalisa Freud tidak berjiwa Islami. Menurut Freud fenomena keagamaan yang terjadi pada individu merupakan sebuah ilusi, yaitu suatu bentuk neorosis yang universal. Selanjutnya Freud mengemukakan teori struktur kepribadian manusia dan konsep Oedipus Complex sebagai asal-usul penyembahan individu terhadap Tuhan ${ }^{1}$ Sejarah pertumbuhan dan pekembangan psikologi di Barat tidak memasukkan unsur yang transcendenta dalam kajian-kajian keduniawian, mereka hanya berdasarkan pada penelitian-penelitian, eksperimen dengan metode empiris dan kajian-kajian ilmiah untuk menetapkan dan pengembangan ilmu-ilmu terapan.

Sedangkan Islam sebagai agama terakhir selalu mendasarkan sikap dan tindakannya kepada aturan-aturan Allah, namun tetap memberikan ruang dan waktu pada akal budi untuk mengkaji segala permasalahan-permasalah yang timbul dalam masyarakat. Kajian jiwa dalam Islam (nafsiologi) didasarkan pada konsep jiwa yang terdapat dalam Al-Qur'an. Islam memandang positif terhadap fungsi akal dan sains, serta segala sesuatu yang berkaitan dengan kegiatan ilmiah. Agama dan sains adalah dua sumber kebenaran yang berbeda, Kebenaran agama adalah kebenaran yang hakiki, sebaliknya

${ }^{1}$ Malik B. Badri, The Dilema of Muslim Psychology, Terj. Siti Zainab Lutfiath, (Jakarta Pustaka Firdaus, 1996), h. 18-19 
kebenaran sains bersifat temporer yang selalu mengalami perubahan melalui kajian pemikiran-pemikiran dan penemuan-penemuan baru.

Nafs dalam nafsiologi dalam bahasa arab disebut dengan aljauhar sebagai substansi penyebab manusia berbeda-beda nilainya (kepribadiannya) dari makhluk lain, Faktor-faktor ini yang menjadikan manusia berbeda-beda dalam hidup, berfikir dan merenung, kemudian dengan pikirannya itu manusia mengambil suatu keputusan. Islam selalu mendasarkan penelitian-penelitiannya kepada al-Qur'an dan ilmu pengetahuan, adanya perbedaan mendasar diantara dua unsur itu memungkinkan terjadimya ketidaksesuaian antara pandangan agama Islam dangan teori-teori kepribadian yang kembang oleh tokoh-tokoh psikologi Barat. Namun, disisi lain kemungkinan terdapat kemiripan antara teori kepibadian menurut Freud dengan konsep nafsiologi dalam Islam. Hal inilah yang menjadi dasar untuk membicarakan antra teori konsep kepribadian manusia menurut Sigmund Freud dan Nafsiologi dalam Islam.

\section{B. Kepribadian Menurut Sigmound Freud}

Sigmund Freud merupakan salah seorang tokoh psikologi Barat, berkembangsaan Jerman, keturunan Yahudi yang lahir pada tanggal 06 Mei 1856 di Freiberg. Ketika Hitler bangkit, Freud melarikan diri ke Inggris dan meninggal di London pada tanggal 23 September 1939. ${ }^{2}$ Roberth H. Thouless menulis bahwa Freud adalah seorang dokter yang menangani gangguan mental yang diklarasifikasikan sebagai individu psikoneorosis. Penyakit-penyakit itu mencakup histeria dengan tanda-tandanya yang disebabkan oleh gangguan mental dan kemudian menimbulkan gangguan organik serta lumpuh, mati rasa atau gangguan pada lambung, cemas, gelisah, dan perasaaan takut yang tiak beralasan (Fobia) serta pelbagai macam tindakan dan perasaan yang dilakukan secara tidak sadar. ${ }^{3}$

Dalam teori kepribadian Freud bahwa manusia terdiri dari tiga sistem/struktur/kepribadian, yaitu 1.Id (Das Es), 2. Ego ( Das

2 Khairunnas Rajab. Psikologi Agama, (Yogyakarta: Aswaja Pressindo, 2012), h. 12

${ }^{3}$ Robert H. Thouless, Pengantar Psikologi Agama, Terj...Machnun Husein, (Jakarta : CV .Rajawali, 1992), h. 10 
Ich), dan 3. Super Ego (Das ueber Ich). Setiap struktur kepribadian itu mempunyai fungsi, sifat, komponen, prinsip kerja, dan dinamisasi serta mekanisme tersendiri. Tetapi diantara komponen-komponen itu saling berinteraksi pada diri undividu, sehingga sulit untuk memisah atau menentukan pengaruhnya terhadap tingkah laku manusia. Sistematika / Struktur kepribadian individu adalah sebagai berikut :

\section{a. Id (Das Es)}

Id adalah sifat bawaan manusia sejak lahir, sebagai sistem ia mempunyai fungsi untuk menunaikan prinsip-prinsip kehidupan secara menyeluruh atau dikenal dengan dorongan naluriah. Menurut Sumadi, bahwa Id adalahn aspek biologis yang merupakan sistem original di dalam kerpibadian. Freud memberi istilah sebagai realitas psikis yang sebenar-benarnya (the true psychic reality), karena Id merupakan perasaan dalam diri individu (emosi) atau perasaan subyektif dari manusia, dan tidak mempunyai hubungan dengan kehidupan dunia yang bersifat obyektif. Justru itu Id berisikan sifatsifat yang ada atau dibawa sejak kelahiran, termasuk insting-insting sebagai reservior sebagai energi psikis yang menggerakan Ego dan Superego. ${ }^{4}$ Bimo Walgito menulis bahwa ... Id (Das Es), adalah dorongan-dorongan, nafsu-nfsu terhadap sesuatu objek, dimana ia menuntut untuk dapat memenuhi dorongan-dorongan atau nafsunafsu tersebut. ${ }^{5}$

Id berkehendak untuk segera tersalurnya kumpulankumpulan energi atau ketegangan-ketegangan dan rangsanganrasangan yang dapat dal;am dirinya, baik datangnya dari dalam maupun dari luar. Id bekerja dan beroperasi berdasarkan "Prinsip Kesenangan (pleaure prinsiple)" dengan tujuan menghilangkan atau mengurangi ketengagan untuk mencapai kenikmatan atau kesenangan. ${ }^{6}$ Kemudian Bernard Paduska menjelaskan bahwa Id bersifat henonistis (mencari kesenangan semata), dan tidak membedakan antara pikiran, dan perbuatan, antara nyata dan hanya

4 Sumadi Suryabrata, Psikologi Kepribadian, (Jakarta : PT.Rajagrafindo Persada, 1995), h. 125

5 Bimo Walgito, Psikologi Sosial; Sutu Pengantar), (Yogyakrt: YP. Fakultas Psikologi UGM, 1980), h. 48

${ }^{6}$ Calviin S. Hall, Libido Kekuasaan Sigmund Freud, Terj. Tasrif, (Jogyakarta: Tarawang Press, 2000), h. 18 
dalam khayalan. ${ }^{7}$ Dengan demikian Id merupakan sifat dasar yang dibawa manusia sejak kelahirnya dan tidak menghirau rintangan dan halangan-halangan untuk mencapai tujuannya, bagi Id yang pasti kepuasannya dapat terpenuhi. Dengan demikian Id dapat dikatakan sebagai sumber tingkah laku manusia dalam berbuat atau sebagai energi penggerak tingkah laku manusia

\section{b. Ego (Das Ich)}

Setelah manusia berhubungan dengan lingkungannya timbullah Ego yang berkedudukan sebagai bagian dari sistem/struktur keribadian individu., Sumadi menjelaskan bahwa " ...Ego adalah aspek psikologis daripada kepribadian dan timbul karena kebutuhan organisme untuk dapat berhubungan secara baik dengan dunia nyata (reality). Orang yang lapar membutuhkan makan untuk menghilangkan ketegangan yang ada dalam dirinya. Ini berarti bahwa organisme harus dapat membedakan antara khayalan dan khayalan tentang makanan. “8

Jalaluddin menjelaskan bahwa Ego berfungsi menyalurkan dorongan-dorongan Id ke ke alam nyata. Selanjutnya Jalaluddin menulis pendapat Freud bahwa ... misi yang diemban oleh Ego dalam diri individu adalah prinsip kenyataan (objective/ relirty prinsiple). Segala bentuk dorongan naluri dari Id hanya dapat direalisasikan dalan bentuk nyata melalui bantuan Ego. Yang mengandung prinsip kesadaran. ${ }^{9}$ Perbedaan antara Id dan Ego terletak pada kenyataan dan tidak nyata, karena Id hanya mengenal kenyataan subyekif jiwa (dunia batin) sesuai dengan kehendaknya, sedangkan Ego membedakan antara sesuatu yang terdapat dalam dunia luar (dunia objektif).

Selanjutnya Ego dapat juga dikatakan sebagai perantara antara dunia batin dengan dunia luar. Sebagai antisipasi agar tidak terjdi ketegangan atau pertentangan diantara dua sifat tersebut dalam jiwa seseorang. Nawawi menulis pendapat Freud bahwa ... Ego berusaha mengendalikan konflik yang terjadi ketika individu

7 Bernard Paduska, Empat Teori Kepribadian, (Jakarta : Restu Agung, 1997),

h. 84

8 Sumadi Surybrata, Psikologi Kepribadian..., h. 126

9 Jalaluddin, Psikologi Agama, (Jakarta ; PT.Raja Grafindo Persada, Cet. I, 1996), h. 161 
mengadakan hubungan dengan dunia luar dengan memberikan pertimbangan kepada Id. Aktivitas sadar dinamakan sebagai persepsi lahiriah, atau persepsi batin atau proses intelektual sedangkan aktivitas prasadar merupakan fungsi ingatan individu. Aktivitas yang tak sadar dikendalikan oleh fungsi pertahanan diri (defense mechanism) Tugas Ego adalah mengatur penyesuaian antara dorongan, keingnan dengan tuntutan realitas atau norma sosial yang berlaku dengan jalan mengendalikan konflik atau masalah yang tercipta dari dorongan yang berusaha mencari pemuasannya. ${ }^{10}$ Fungsi Ego adalah mencoba memperingatkan tindakan-tindakan Id yang tidak sesuai dengan kenyataan yang terdapat dalam masyakarat agar dijauhi atau ditinggalkan. Ego mencoba menetralisir keinginan-keinginan Id yang tidak sesuai dengan kenyataan yang ada.

\section{c. Superego (das Ueber Ich).}

Superego merupakan salah satu unsur moral dan keadilan dalam kehidupan manusia. Abdul Aziz Ahyadi menulis bahwa ... dalam struktur kepribadian super ego adalah hasil perkenalannya dengan norma sosial budaya, sehingga erat hubungannya dengan moralitas dan kebutuhan kebutuhan rohaniah ${ }^{11}$ Sumadi menulis bahwa: Dalam struktur kepribadian Superego termasuk aspek sosiologis kepribadian sebagai wujud internal dari nilai-nilai tradisional serta nilai-nilai kemasyarakatan. Sebagaimana diajarkan orang tua kepada anak-anaknya dengan berbagai perintah dan larangan yang harus dilakukan oleh individu dalam hidup. Superego lebih tertuju ke arah kesempurnaan daripada kesenangan hidup. Selain itu, Superego dapat pula dianggap sebagai aspek moral kepribadian yang mempunyai fungsi pokok dalam menentukan baik dan buruk., sehingga individu menjunjung tinggi moralitas masyarakat $^{12}$

Super Ego dalam kegiatannya selalu mendominasi unsurunsur moral dan keadilan dalam hidupnya dan pemegang referensi alam ideal,. Tujuan Superego adalah membawa individu kearah kesempurnaan sesuai dengan pertimbangan keadilan dan moral yang

10 Rifat Syauqy Namawi, (Ed), Metodologi Psikologi Islami, (Yogyakarta: Pustaka Pelajar, 2000), h. 42

11 Abdul Aziz Ahyadi, Psikologi Agama Kepriobadian Muslim Pancasila, (Bandung: CV. Sinar baru Offset, Cet. I, 1988), h. 77

12 Sumadi Suryabrata, Psikologi Kepribadian..., h. 127 
berkembang dalam masyaraakat. Superego menuntut kesempurnaan dan idealitas perilaku dengan ketaatan kepada norma adan aturanatuan yang berlaku dalam masyarakat sehingga dikatakan bahwa pada Superego berlaku "Prinsip Idealitas"

Sigmund Freud dalam Budiraharjo membagi Superego yang bersifat ideal ini ke dalam dua komponen, yaitu suara bati (conscience) dan ego ideal. Suara hati adalah berupa hukuman yang diberikan oleh lingkungan terhadap individu, misalnya hukuman yang diberikan oleh orang tua, atau masyarakat sedangkan ego ideal didapati melalui penerimaan hadiah. ${ }^{13}$ Kata hati adalah suara-suara mengenai keberatan-keberatan terhadap gerak-gerik hati yang ada dalam diri kita, tetapi penekanannya terletak pada kenyataan bahwa penolakan ini tidak harus tergantung pada hal apa pun. ${ }^{14}$

Secara psikologis, manusia terdorong untuk melakukan sesuatu yang baik, dan benar, tetapi muncul pula naluri yang mendorong manusia untuk melakukan sesuatu yang bertentangan dengan realitas yang ada dalam masyarakat. Umpanya; timbul keinginan untuk makan, tetapi makanan tidak ada, untuk memenuhi keinginan tersebut, maka muncullah dorongan untuk mencuri makanan. Jika perbuatan itu dilaksanakan, maka Ego akan merasa bersalah, akan mendapat hukuman dari Ego Ideal, yang mengakibat timbulnya kegelisahan atau tidak tenteram dalam dirinya. Sebaliknya, jika dorongan untuk mencuri makanan tidak jadi dilaksana, maka Ego akan memperoleh penghargaan atau pujian dari hati nurani (conscience) akibatnya timbullah perasaan senang dan bahagia dalam diri individu. Suasana inilah yang membawa indvidu merasa bahagia atau berdosa.

Keinginan-keinginan yang tidak yang terpenuhi ini akan menimbulkan ketegangan pada diri individu. Menurut Sumadi bahwa sumber ketenangan pokok yang berhubungan dengan perkembangan kepribadian adalah: 1). Proses petumbuhan fisiologi; 2). Frustrasi; 3). Konflik; dan 4). Ancaman. Dengan adanya hal tersebut, individu perlu mereduksi ketegangan dengan belajar

13Paulus Budiraharjo (Ed), Mengenal Teori Kepribadian Mutakhir, (Yogyakarta: Kanisius, 1997), h. 22

14 Sigmund Freud, Totem and Taboo, Terj.. Kurniawan, (Jogyakarta: Jendela Grafika, 2001), h. 111 
menggunakan cara-cara baru yang disebut perkembangan kepribadian. ${ }^{15}$

Selain itu, karya Freud yang orisinil dan monumental adalah berkenaan dengan tiga strata kesadaran manusia, yaitu alam sadar (the Conscious), alam prasadar (the preconscious), dan alam tak sadar (the unconscious) ketiga bentuk strata itu secara dinamis berintegrasi antara satu dengan lainnya. Bastaman menulis bahwa: " Pandangan Freud tentang jiwa manusia dapat diumpamakan sebagai gunung es yang terapung di samudera yang terdiri dari; sebagian kecil tampak dipermukaan (Alam Sadar), bagian terbesar tidak tampak karena ada didalam samudera (Alam Tak Sadar), dan di antara keduanya ada bagian yang karena gerakan naik-turunnya gelombang kadang-kadang hilang terendam oleh air lau namun bila air laut turun maka kelihatan gunung es berada dipermukaan laut, kondisi ini disebut Alam Prasadar ${ }^{16}$ Peristiwa-peristiwa ini sering ditemui dalam kehidupan individu misalnya; ketika individu mengucapkan kata-kata itu benar atau sesuai dengan kenyataan yang ada, berarti pada waktu itu indvidu berada dalam wilayah alam sadar, dan sebaliknya bila perkataan yang diucapkanya itu tidak benar berarti individu berada dalam tidak dasar, karena alam sadarnya tertutup oleh air laut yang menutupi alam prasadarnya.

\section{Struktur Kepribadian Dalam Nafsiologi}

Dalam bahasa Indonesia, kata nafs selalu diartikan dengan kata kepribadian, Fazlur Rahman menulis bahwa perkataan nafs yang ada dalam al-Qur'an diterjemahkan dengan kata jiwa, yang berarti kepribadian atau keakuan. ${ }^{17}$ Al-Qur'an mengisyaratkan bahwa nafsu sebagai sisi dalam dari sikap manusia yang berhubungan dengan dorongan-dorongan tingkah laku dan sikap manusia. Dalam perkembangannya, kepribadian manusia tidak terpisahkan antara aspek dalam dan aspek di luar dirinya. Untuk mudah memahami pengertian istilah nafsiologi Islam, dipakailah kata nafs untuk

15 Sumadi Subrata, Psikologi Kepribadian..., h. 141

16 Hanna Djumhana Bastaman, Integrasi Psikologi Dengan Islam MenudjuPsikologi Islami, (Yogyakarta:,Et. II, Pustaka Pelajr Offiset, 1997), h. 45

17, Fazlu Rahman, Major Themes of the Qur"an'an, Terj. Amas Muhyiidin, (Bandung Pustaka, 1983), h, 26 
menyebutkan kepribadian manusia dalam membicarakan struktur kepribadian menurut pandangan nafsiologi.

Achmad Mubarok menulis bahwa nafs adalah al-jaubar atau substansi yang menyebabkan manusia berbeda kualitasnya dengan makhluk yang lain, yakni yang menyebabkan manusia mampu menggagas, berfikir dan merenung, kemudian dengan pikiran manusia mengambil keputusan, dan dengan pikirannya itu juga dapat mengungkapkan membuka rahasia dari tanda-tanda $\mathrm{r}$ dan simbol-simbol yang membuatnya harus memilih jalan mana yang harus ditempuh. Lebih lanjut Mubarok menjelaskan bahwa ; “... Dalam Islam nafs merupakan wadah, juga sebagai penggerak tingkah laku manusia. Tuhan tidak mengubah nasib suatu kaum sebelum mereka mengubah kedaannya sendiri atau jiwanya. Bila individu bisa dioptimalkan fungsi nafs, niscaya akan menjadi penggerak manusia untuk melakukan tingkah laku atau perubahanperubahan dalam kehidupnnya. Sebagai wadah nafs menampung halhal yang baik maupun yang buruk..."18 Dalam al-Qur'an, diterangkan bahwa nafs memiliki kemerdekaan dan berpeluang untuk melakukan perbuatan baik dan meninggalkan perbuatan tercela, tergantung kepada faktor-faktor yang mempengaruhinya. Hal itu tergantung kepada manusia untuk dapat mengendalikan kodrat fitriahnya, tabi'at individualnya serta daya respon terhadap lingkungannya.

Sukanto dan A. Dardiri Hasyim, menulis bahwa “ ... dalam al-Qur'an ada dua konsep yang bersifat abstrak yang selalu membeingungkan karena manusia sulit membedakan antara penyakit nafs dan ruh.. Ada orang yang berkata, bahwa dengki, takabur, cemas, kecewa dan sebagainya itu termasuk penyakit rohaniah. Sesungguhnya hal tersebut bukanlah ruh, tetapi merupakan nafs . Sesuatu yang dikeluarkan dari orang mati itu bukan ruh, tetapi nafs...." ${ }^{\prime 19}$ Dengan demikian yang dibangiktkan dari alam kubur adalah nafs, bukan ruh. Sedangkan perasaan resah, gelisah, putus asa, frustrasi dan sebagainya adalah gejolak nafsiah. Sedangkan ruh itu adalah getaran Ilahiah atau getaran sinyal ketuhanan yang diberikan kepada manusia, sebagaimana rahmah, nikmat, berkah dan hikmah

${ }^{18}$ Achmad Mubaraok, Solusi Krisis Keruhanian manusia modern JIwa Dalam Al-Qur'an, (Jakarta : Penerbit Paramadina , Cet. I, 2000), h. 53

19 Sukanto dan A.Dardiri Hisyam, Nafsiologi Refleksi Analisa Tentang Diri dan Tingkah laku Manusia, (Surabaya : Risalah Gusti, 1995), h. 41 
yang sering dirasa sentuhannya oleh manusia, tetapi manusia tidak dapat memahami hakikatnya, karena masalah ruh adalah urusan Tuhan.

Nafsiologi muncul dan berusaha memperkenalkan gejalagejala nafsiologis yang berkaitan dengan berbagai sifat terpuji dan tercela bagi manusia, dalam pengalaman hidup berkepribadian, bermusyarwarah, dan berketuhanan. Apabila psikologi sebagai salah satu bidang science of man telah melepaskan kajiannya tentang kualitas manusia, dan tentang hubungan manusia dengan Tuhannya, maka nasiologi justru berkehendak menegakkan kedua jalur tersebut dalam kehidupan manusia sebagai makhluk Allah. Secara struktural bahwa kesatuan nafs dan tubuh itu merupakan kesatuan bulat yang meliputi seluruh organ tubuh. Dalam al-Qur'an dijelaskan bahwa insan itu adalah makhluk kesatuan nafsio-fisik atau makhluk kesatuan nafsiahjasmaniah yang dapat dikaji dalam nafsiologi. Stuktur Kepribadian dalam nafsioligi, terdiri dari beberapa bagian

a. Qalb (Angan-angan / kehatian)

Menurut istilah, Qalb; berarti sesuatu yang berbolak-balik atau sesuatu yang lebih. Secara biologis Qalb diartikan sebagai segumpal daging. Secara nafsilogis, qalb dapat diartikan sebagai pedoman kehidupan manusia. Qalb adalah "reservoir" energi yang menggerakan Ego dan Fuad. Ramayulis mengutip hadist yang diriwayatkan oleh Bukhari dan Muslim, artinya; " Ketahuilah bahwa di dalam tubuh manusia terdapat sekepal daging. Kalau itu baik, baiklah seluruh tubuh. Kalau itu rusak, rusaklah seluruh tubuh. Itulah QALB". ${ }^{20}$

Bila dikaji secara psikologi ada kesamaan antara teori kepribadian Sigmound Freud dengan teori kepribadian Sukanto. Menurut Freud bahwa id memiliki kekuatan insting-insting atau keinginan-keinginan yang harus dilaksanakan atau dipenuhi tanpa menghiraukan sumber dan bentuknya, bagi id berlaku prinsip kenikmatan. Sedangkan qalb dalam nafsilogi adalah bentuk segumpal darah yang berarti bolak-balik, dapat dijadikan sebagai standar bagi perbuatan manusia, qalb bertujuan untuk mememuhi keinginannya yang bersifat tidak tetap atau bolak- balik seseuai bentuk atau

${ }^{20}$ Ramayulis, Psikologi Agama, (Bandung: Kalam Mulis, Cet. VI, 2003), h. 
sumber keinginan yang dikehendaki. Fungsi Qalb bagi nafs selalu menuntut kepuasan bagi individu,maka Qabl menganut "pleasure principle", yang menghendaki gar segala kehendak dan keinginannya terpenuhi atau dilaksanakan, Kalau telah yang di inginkannya terpenuhi maka ia menuntut keinginan yang lainnya.

b. Fuad (Perasaan/hati nurani/ulu hati)

Jalaluddin menulis bahwa; Fuad adalah suatu perasaan yang paling terdalam dari hati manusia dan biasanya sering disebut dengan "hati nurani" (cahaya hati), dan penentu manusia dalam bersikap, bertingkah laku dan berbut Selain itu Fuad atau hati nurani berfungsi sebagai penyimpan daya ingatan dan selalu bersikap benar dalam hidupnya. Ia sangat sensitif terhadap gerak atau dorongan hati, dan meresakan akibatnya. ${ }^{21}$

Kemudian Hanna Djumhana Bastaman menulis bahwa hati nurani adalah salah satu aspek terdalam dari jiwa manusia yang senantiasa menilai benar-salahnya perasaan, niat, angan-angan, pemikiran, hasrat, sikap dan tindakan seseorang. ${ }^{22}$

Fuad dalam hidupnya selalu jujur dan tidak pernah berbohong baik terhadap dirinya sendiri maupun terhadap orang lain, dengan kata lain apa yang terrsimpan dalam dirinya itulah yang kelihatan, disamping itu fuad sangat sensiitif terhadap dorongan atau gerak hati, dan merasakan akibatnya. Ramayulis menulis bahwa bila hati terancam oleh bahaya, atau hati tersentuh sesuatu yng tidak menyenangkin, fuad terasa terbakar, atau gelisah dalam dirinya. Sebaliknya bila seseorang merasa tenang dalam diirinya, maka fuad pun menjadi tenteram dan senang dalam hidupnya. Fuad tidak bisa mengkhianati kesaksian terhadap apa yang dipantulkan oleh hati

c. Ego (Aku sebagai pelaksana dari kepribadian)

Ego marupakan aspek eksekutif kepribadian manusia yang timbul dari keinginan untuk berhubungan dengan kenyataan. Ramayulus menulis bahwa; ... “... Aspek ini timbul karena kebutuhan organismme untuk dapat berhubungan secara baik dengan kehidupan nyata (realita). Ego dikatakan sebagaai aspek

${ }^{21}$ Jalaluddin, Psikologi Agama..., h. 163

22 Hanna Djumhana Bastaman, Integrasi Psikologi Dengan Islam Menuju Psikologi Islami, (Yogyakarta : Pustaka Pelajar Cet. II, 1997), 1. 147 
eksekutif dlam struktur kepribadian manusia Berfungsi sebagai alat kontrol cara-cara yang ditempuh, memilih kebutuhan-kebutuhan, dan memilih obyek-obyek yang bisa memenuhi kebutuhan, serta mempersatukan pertentangan-peertentangan antara qalb dan fuad. ${ }^{23}$

Ego berfungsi untuk merealisaasikan kebutuhan-kebutuhan qalb dengan jalan memilih bentuk pemuasan kenikmatan yang benarbenar ada dan tersedia, dan apakah caranya mendapatkannya telah sesuai dengan norma-norma yang berlalaku Berdasarkan sistem kerja bagi ego berlakuk Prinsip Realitas. Ego berfungsi untuk meredakan ketegangan dalam diri individu dengan cara melakukan aktivitas penyesuaian dorongan-dorongan yang ada dengan kenyataan objektif. Ego memiliki kesadaran untuk menyelaraskan dorongan baik dan buruk hingga tidak terjadi kegelisahan-kesgelisaahan dalam hidup atau kehendak manusia.

Kemudian ego dikatakan juga sebagai derivat dari qalb, dan karena qalb hanya mengenal dunia sebagai sesuatu yang subjektif dan objektif (dunia realitas). Secara prinsip ego berpegang pada prinsip kenyataan (Reality Principle). Tujuan prinsip kenyataan pada Qalb adalah mencari objek-objek yang tepat (sesuai) untuk dapat meredakan ketegangan-ketegangan psikologis manusia. Dan sistem kerja ego merumuskan apakah suatu tindakan akan dilaksanakan atau dibatalkan

\section{d. Tingkah Laku}

Dalam teori psikologi, tingkah laku timbul ketika pemikiran individu bertemu dengan suatu obyek. Jalaluddin menulis bahwa; Dalam nafsiologi kepribadian berangkat dari kerangka acuan dan asumsi-asumsi subyektif tentang tingkah laku manusia, karena manusia selalu mengemukakan hal-hal yang bersifat subyektif dalam hidupnya. Selanajutnya beliau menegaskan bahwa tingkah laku manusia ditentukan oleh keseluruhan pengalaman-pengalaman yang disadari oleh pribadi... ${ }^{24}$ Apa yang difikirkan dan dirasakan oleh indivdu akan menentukan apa yang akan dikerjakannya, baik dan buruknya nilai perbuatan yang dikerjakan oleh seseorang tergantung kepada lingkungannya.

${ }^{23}$ Ramayulis, Psikologi Agama..., h. 136

24 Jalaluddin, Psikologi Agama..., h. 165 
Dengan kata lain, munculnya tingkah laku disebabkan bertemunya pemikiran seseorang dengan objek yang dikehendakinya, maka munculah sikap terhadap objek yang diiringi oleh motif untuk melskuksn tingkah laku terhadap objek tersebut. Apakah tinghkah laku yang dilakukan itu bersifat normal atau tidak normal ditentukan oleh nilai-nilai dan norma yang bersifat umum. Ramayulis menjelaskan bahwa orang yang normal adalah orang yang secara optimal telah beriman dan dan melaksanakannya dalam bnetuk amal shaleh di segala tempat. Kebalikan individu yang keluar dari dari ketentuan itu disebut dengan abnormal dalam bentuk sifat-sifat dhalim, fasiq, syirik, kufur, nifaq. ${ }^{25}$

Mujib dalam Ramayulis menulis bahwa, struktur kepribadian dalam pandangan Islam adalah fithrah. Struktur fithrah individu memiliki tiga dimensi; (1) dimensi pisik yaitu keadaan yang nyata disebut dengan fithrah jasmani, (2) dimensi psikis yaitu keadaan jiwa manusia yang disebut dengan fithrah rohani, (3) dimensi psikologis yang disebut dengan fithrah nafsani. ${ }^{26}$ Setiap dimensi mempunyai tugas dan tanggung jawab, selanjutnya sistem kerja dari ketiga dimensi diatas saling terkait antara satu dengan lainnya, ia selalu bekerja sama dalam melakukan sesuatu, namun sebagai penentu adalah fithrah nafsani.

Pertama, dimensi pisik disebut dengan fithrah jasmani, kesubtansian fitrah jasmani tidak dapat membentuk secara langsung kepribadiannya sendiri tetapi membutuhkan substansi lain, karena keberadaan manusia bukan ditentukan oleh fitrah jasmani, melainkan ditentukan atau ditetapkan oleh fitrah. Sukanto menulis bahwa: Dengan demikian nafsil insaniah (kepribadian manusia) dalam perkembangannya tidak pernah tampil sebagai nafs tanpa fisik, atau fisik tanpa nafs. Aktivitas nafs tanpa fisik adalah imajinasi (khayal). Sedangkan aktivitas fisik tanpa nafs adalah robot. Hanya maut yang dapat memisahkan nafs dari fisik. ${ }^{27}$

Kedua, Dimensi psikis yang disebut dengan fithrah rohani, manusia sebagai makhluk rohani selalu berkomunikasi atau

25 Ramayulis, Psikologi Agama..., h. 136

${ }^{26}$ Ibid, h. 136

${ }^{27}$ Sukanto dan A. Dardiri Hisyam, Nafsiologi Refleksi Analisa Tentang Diri dan Tingkab laku Manusia, (Surabaya : Risalah Gusti, 1995), h. 67 
berhubungan dengan Tuhan. Sebelum manusia dilahirkan kedunia manusia mengadakan transaksi dengan Khaliknya. Ramayulis menjalaskan bahwa: ... " meskipun fitrah rohani belum masih terpisah jasmaninya, namun ia memiliki eksistensi tersendiri di alam arwah. Sedangkan psikolog Barat memandang Fitrah rohani berbeda dengan jiwa. Ia di alam arwah telah mengadakan perjanjian (al-mitsaq) dengan Allah SWT. Perjanjian itu berupa penerimaan amanatsebagai energi psikis yang memberikan motivasi kehidupan keagamaan manusia. $^{28}$

Transaksi yang terjadi antara Tuhan dan manusia, maupun antar sesama manusia sebagai sistem kerja energi, sebagaimana firman Allah dalam al-qur'an yang berarti : Manusia akan dtimpa rasa kehinaan di nama saja mereka berada, kecuali jika mereka berpegang kepada tali (agama) Allah dan tali (perjajian ) dengan manusia... ${ }^{29}$ (Surat Ali Imran ayat 3 ).

Dalam pandangan nafsilogi, kedua iktan perjanjian itu sebenarnya tidak dapat dipisahkan, keduanya membentuk hubungan komplementer dan simbolisis. Makna tali Allah adalah berupa akidah sedangkan makna tali manusia adalah berbentuk muamalat dan amaliah. Akidah dan muamalat berfungsi saling membutuhkan, dan akan bertemu dalam titik konvergensi sebagai suatu sistem nilai. Ketiga, fithrah nafsani merupakan gabungan antara jasamani dan rohani dimensi psikopisik manusia yang terdiri dari aspek psikis yang berasal dari fithrah rohani dan aspek pisik berasal dari fithrah jasmani, keduanya saling terkait dan mengandung beberapa daya pokok, sebagaimana ditulis Ramayulis; Fithrah nafsni yang terdapat pada manusia merupakan dimensi psikopisik manusia. Ia memiliki tiga daya pokok, yaitu kalbu (struktur supra kesadaran), akal (struktur kesadaran), dan nafsu (struktur bawah sadar). Masing-masing daya memiliki dua natur, yaitu natur kejasmanian dan kerohanian.. ${ }^{30}$

Aspek psikis fithrah nafsani sangat terkait dengan aspek pisiknya. Pertumbuhan aspek pisik sangat berkolerasi dengan perkembangan aspek psikis, walaupun aspek psikis lebih dominan

${ }^{28}$ Ramayulis, Psikologi Agama..., h. 137

29 Dep. Agama RI, Al-Quraan dan Terjemahannya, (Jakarta : Proyek Pengadaan Kitab Suci Al-Qur'an, Depag R.I, 1981/1982), h. 94

${ }^{30}$ Ramayulis, Psikologi Agama..., h. 137 
daripada aspek pikisnya. Aspek psisik berasal dari fithrah rohani, sedang aspek pisik berasal dari fithrah jasmani

\section{Penutup}

Menurut Sigmound Freud manusia memiliki tiga sistem/struktur kepribadian yaitu ; 1). Id (Das Es), menganut "Prinsip Kenikmanatan " dalam tindakannya. 2). Ego ( Das Ich), "berprinsip Realitas" dalam kehidpannya. dan 3). Super Ego (Das ueber Ich) menganut Prinsip Idealitas bagi kehiupan individu. Setiap bagian dari kepribadian itu mempunyai fungsi, sifat, komponen, prinsip kerja, dan dinamisasi serta mekanisme tersendiri yang bekerja dalam diri manusia. Diantara komponen-komponen itu saling berinteraksi dalam diri individu, sehingga sulit untuk memisah atau menentukan pengaruhnya terhadap tingkah laku manusia.

Perkataan nafs dalam al-Qur'an diartikan dengan kata jiwa, atau keakuan, nafsiologi dalam Islam, adalah suatu istilah untuk menyebutkan dan membicarakan struktur kepribadian manusia, sedangkan struktur kepribadian perspektif Islam dikenal dengan sebutan fitrah. Stuktur Kepribadian dalam nafsioligi, terdiri dari 1). Qalb ( angan-angan atau kehatian) yang berarti keadaan jiwa manusia yang bersifat berbolak-balik dalam menetapkan sesuatu. Secara biologis Qalb adalah sebagai segumpal daging. 2).Fuad (perasaan/hati nurani/ulu hati) yaitu perasaan manusia yang paling dalam yang terletak diulu hati manusia, sering disebut dengan hati nurani dan berfungsi sebagai penentu manusia dalam bersikap. Ia sangat sensitif terhadap gerak atau dorongan hati yang meresakan jiwa manusia, secara nafsiologis, qalb dapat diartikan sebagai radar kehidupan 3). Ego (aku sebagai pelaksana dari kepribadian) sebagai aspek eksekutif kepribadian manusia yang timbul dari keinginan untuk berhubungan dengan kenyataan. Ego muncul dalam diri manusia dikarenakan kebutuhan organisme untuk berhubungan secara baik dengan kehidupan dunia nyata. Ego memiliki prinsip kenyataan (realitas). Berfungsi untuk mengontrol dan menetralisir pertentangan-peertentangan antara qalb dan fuad dalam memilih kebutuhan-kebutuhan, dan menentukan obyek dan syarat-syaratnya yang bisa memenuhi kebutuhan, 4). Tingkah laku yang terjadi pada manusia ketika pemikiran individu bertemu dengan obyek-objek yang dikendakinya. Tingkah laku itu ditentukan oleh keseluruhan pengalaman yang disadari oleh pribadi. 
Struktur fithrah dalam Islam terdiri fdari tiga bentuk ; (1) fithrah jasmani yang berasal dari dimensi pisik , (2) fithrah rohani yang brmula dari dimensi psikis, (3) fithrah nafsani disebut juga sebagai dimensi psikologis Dan setiap bentuk dimensi mempunyai tugas dan tanggung jawab, sistem kerja dari ketiga dimensi diatas saling terkait antara satu dengan lainnya, dan selalu bekerja sama dalam melakukan sesuatu, namun sebagai penentu adalah fithrah nafsani 


\section{Daftar Pustaka}

Ahyadi, Abdul Aziz, Psikologi Agama, Kepribadian Muslim Pancasila, Bandung: CV. Sinar Baru Offiset, Ce.I, 1998

Bastaman, Hanna Djumhana, Integrasi Psikologi Dengan Islam Menuju Psikologi Islami, Yogyakarta: Pustaka Pelajar, Cet.II, 1997

Badri, Malik B, The Dilema of Muslim Pscchology, Terj. Siti ZingLutfiah, Jakarta : Pustaka Firdaus, 1996

Freud Sigmound, Totem and Taboo, Terj. Kurniawan, Jogyakarta, Jendela Grafika, 2001

Jalaluddin, Psikologi Agama, Jakarta ; PT.Raja Grafindo Persada, Cet. I, 1999

Hall, Calvin S., Libido Kekuasaan Sigmund Freud, Terj. Tasrif, Jogyakarta : Tarawang Press, 2000,

Mubarok, Achmad Solusi Krisis Keruhanian manusia modern JIwa Dalam Al-Qur'an, Jakarta : Penerbit Paramadina , Cet. I, 2000,

Bernard Paduska, Empat Teori Kepribadian, Jakarta : Restu Agung, 1997.

Namawi, Rifat Syauqy (Ed), Metodologi Psikologi Islami, Yogyakarta: Pustaka Pelajar, 2000

Ramayulis Psikologi Agama, Bandung: Kalam Mulis, Cet. VI, 2003

Hanna Djumhana Bastaman, Integrasi Psikologi Dengan Islam Menuju Psikologi Islami Yogyakarta : Pustaka Pelajar Cet. II, 1997

Khairunnas Rajab. Psikologi Agama, Yogyakarta: Aswaja Pressindo, 2012

Rahman, Fazlu Major Themes of the Qur"an'an, Terj. Amas Muhyidin, Bandung Pustaka, 1989

Sukanto dan A.Dardiri Hisyam, Nafsiologi Refleksi Analisa Tentang Diri dan Tingkah laku Manusia Surabaya: Risalah Gusti, 1995

Sumadi Suryabrata, Psikologi Kepribadian, Jakarta: PT.Rajagrafindo Persada, 1995, 
Sigmund Freud, Totem and Taboo, Terj. Kurniawan, Jogyakarta : Jendela Grafika, 2001

Thouless, Robert H. Pengantar Psikologi Agama, Terj.Machnun Husein, Jakarta : CV . Rajawali, 1999

Walgito, Bimo Psikologi Sosial (Sutu Pengantar), Yogyakrt: YP.Fakultas Psikologi UGM, 1980. 